\title{
Harvesting energy from in-pipe hydro systems at urban and building scale
}

\author{
Marco Casini* \\ Department of Planning, Design, and Technology of Architecture (PDTA), Sapienza University of Rome, Via Flaminia 72, 00196 - \\ Rome, Italy
}

\begin{abstract}
In addition to photovoltaic and wind systems, nowadays in-pipe water to wire power systems are becoming particularly interesting for the integration of renewable resources at urban and building scale because of the potential to harness clean energy from excess head pressure in urban and domestic water pipelines. Able to operate across a wide range of head and flow conditions, these particular micro hydro power systems can be deployed in municipalities, energy-intensive industries and agricultural irrigation districts providing a consistent amount of clean and continuous energy without the typical intermittency of wind and solar and at the same time helping in pipelines management and maintenance. The article presents an overview of the different types of in-pipe hydro systems available on the market and illustrates their possible applications at the urban and building scale and the benefits achievable in terms of energy production compared to other renewable such as photovoltaic and wind systems.
\end{abstract}

Keywords: In-pipe hydro systems, energy harvesting, renewable energy, small hydro, building integrated renewable energy, renewable energy at urban scale, distributed energy

\section{Introduction}

Hydropower is a mature and cost-competitive renewable energy source that plays a strategic essential role in XXI century electricity mix, contributing to more than $16 \%$ of electricity generation worldwide (more than $3500 \mathrm{TWh}$ ) and about $85 \%$ of global renewable electricity [1], [2]. In use in over 160 countries, hydropower capacity is on the rise, reaching $1.31 \mathrm{TW}$ worldwide at the end of 2011 [3] against $369 \mathrm{GW}$ of wind [4] and $177 \mathrm{GW}$ of photovoltaic at the end of 2014 [5].

Hydroelectricity presents several advantages over most other sources of electrical power, including a high level of reliability, proven technology, high efficiency (about 90\% efficiency, water to wire), very low operating and maintenance costs, flexibility and large storage capacity. Furthermore, hydropower systems can help stabilizing fluctuations between demand and supply supporting the variability of other renewable energy sources such as wind power and photovoltaic electricity, whose production is growing considerably worldwide.

The great variety in the size of hydropower plants allows this technology to adapt to both large centralized and small scale urban distributed energy model needs. Recently, thanks to the development of small hydro turbines, compact and specified for urban use, it is possible to harness water power for onsite energy generation or domestic production or industrial and agricultural districts.

\section{Hydro Power Classification by Capacity}

Hydro Power plants capacities range from several watt (W) for the smallest individual installations, to tens of gigawatt $(\mathrm{GW})$ for the largest. Depending on the installed capacity, hydropower systems are

\footnotetext{
* Manuscript received April 30, 2015; revised September 15, 2015.

Corresponding author. Tel.: +390637514322; E-mail address: marco.casini@uniroma1.it.

doi: 10.12720/sgce.4.4.316-327
} 
classified into "large hydro" (over $10 \mathrm{MW)}$ or "small hydro" (up to $10 \mathrm{MW}$ ). Small systems are in turn divided in "mini-hydro" (up to $1 \mathrm{MW}$ ), "micro-hydro" (up to $100 \mathrm{~kW}$ ) and "pico-hydro" (up to $5 \mathrm{~kW}$ ). HPP with capacity lower than $10 \mathrm{MW}$ are estimated to represent about $10 \%$ of the global HPP capacity [6].

These size based subdivision represent an average size reference as there is no global agreement between different countries on the classification of hydro systems according to the installed power, with the consequence that the definition of small-scale hydro spans a very wide range of plants sizes. As shown in Table 1, various countries, or groups of countries, define 'small hydro' differently, from below 1.5 MW in Sweden to below 50 MW in China.

This broad spectrum in definitions of size categories is motivated by local energy and resource management needs of different countries such as national licensing rules to determine which authority is responsible for the process (e.g., Norway) or the need to define eligibility for specific support schemes (e.g., US Renewable Portfolio Standards).

Table 1. Small-scale hydropower by installed capacity (MW) as defined by various countries [7]

\begin{tabular}{lll}
\hline Country & $\begin{array}{l}\text { Small-scale hydro as defined by } \\
\text { capacity (MW) }\end{array}$ & Reference \\
\hline Brazil & $\leq 30$ & Brazil Government Law No. 9648, of May 27, 1998 \\
Canada & $\leq 50$ & Natural Resources Canada, 2009 \\
China & $\leq 50$ & Jinghe (2005), Wang (2010) \\
European Union & $\leq 20$ & Directive 2004/101/EC ("Linking Directive") \\
India & $\leq 25$ & Ministry of New and Renewable Energy, 2010 \\
Norway & $\leq 10$ & Norwegian Ministry of Petroleum and Energy 2008 \\
Sweden & $\leq 1.5$ & European Small Hydro Association \\
United States & $5-100$ & US National Hydropower Association \\
\hline
\end{tabular}

Due to their ease of construction and integration into local environments, the deployment of small hydro power systems is increasing in many parts of the world, especially in remote areas where other energy sources are not viable or not economically attractive.

Among systems with power up to $100 \mathrm{~kW}$ (micro hydro), particularly interesting for the potential of integration at urban and building scale are in-pipe hydro power systems.

Designed for gravity fed and pressurized transmission and distribution lines as well as effluent outfalls and other pipe conveyance systems, these particular micro hydro systems may be located in municipal water or waste water systems, industrial water systems, or irrigation systems.

In-pipe hydro systems can operate across a wide range of head and flow conditions inside most common piping materials such as steel, ductile iron, concrete, or any material that can be mated with steel pipe, providing clean, baseload energy without the intermittency of wind and solar and without environmental repercussion. Since most of piping runs underground, such systems are also protected from vandalism, theft or weather accidents and are compatible even with historical cities or locations with strict visual regulations.

The ideal sites are where pipeline construction or maintenance is scheduled to take place. Retrofit sites are also ideal especially when situated next to electrical loads, pipes above ground or below ground with vault access.

Another benefit of integrating in-pipe hydro systems is the possibility to better control overpressure and lower it where necessary, thus preventing leaks in aging infrastructure and elongating service life of all piping equipment

\section{In pipe Hydro Power Systems}

In pipe hydro power systems can be divided in two main designs:

- Internal systems, where the runner is wholly inside the pipe section and only the generator protrudes from the conduit ;

- External systems, where the runner is contained in a secondary conduit that bypasses the main one. 


\subsection{Internal systems}

Internal systems (Fig. 1) have the advantage of a more compact size that makes them more suitable, but not restricted, for smaller applications. Power output ranges from 5-10 watts, sufficient to supply self powered water metering or monitoring systems, to $100 \mathrm{~kW}$ for more energy intensive applications.

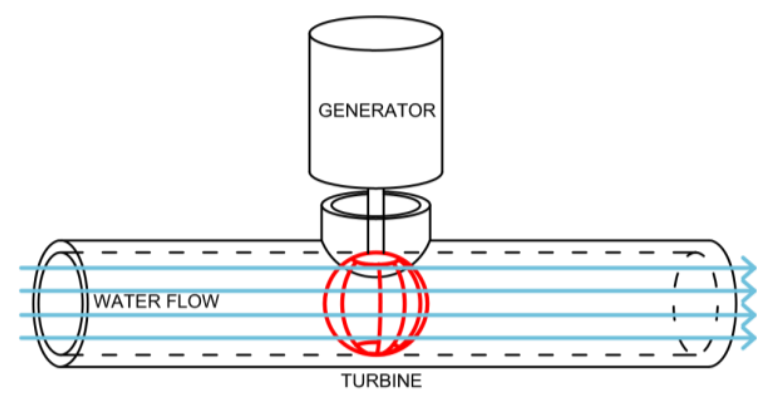

Fig. 1. Internal systems .

Fig. 2. Fuji micro tubular water turbine.

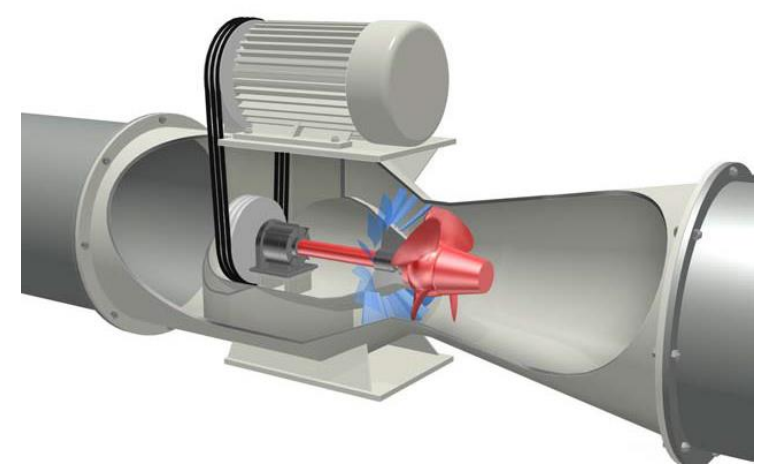

Internal systems are based on traditional in line impellers (Hydro-spin), tubular turbines as Micro Tubular Water Turbine (Fig. 2) and Linepower, or more innovative designs such as Archimedes coils (Hydro-coil, Fig. 3), all with horizontal axis parallel to the water flow. Lucidpipe Power System generators (Fig. 4) employ a Gorlov design vertical axis turbine instead, allowing for a simpler design since the turbine shaft is already aligned with the generator.

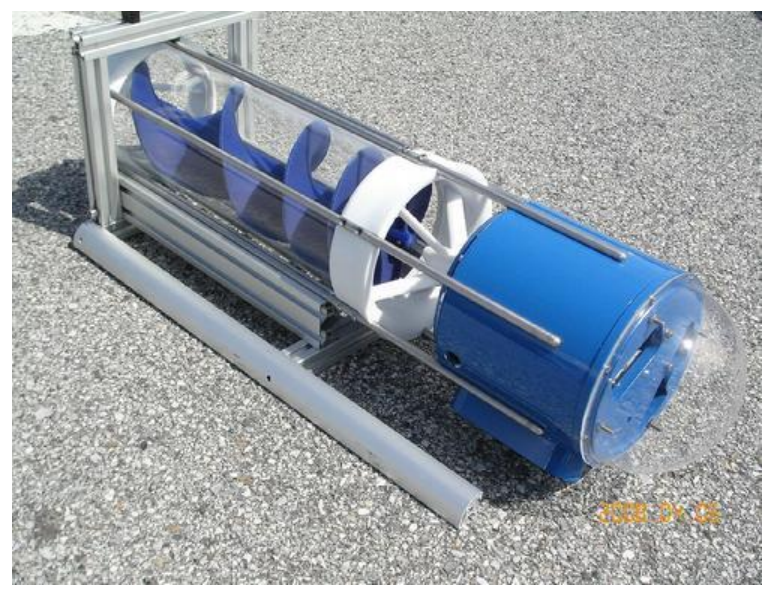

Fig. 3. Hydro-Coil 600. 


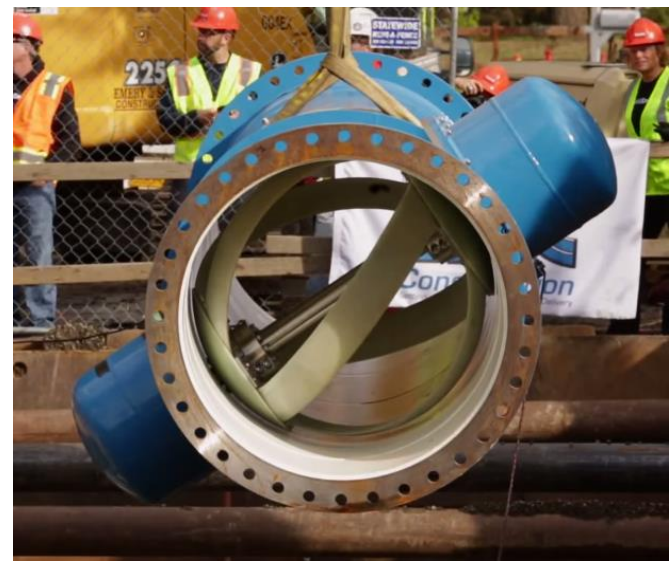

Fig. 4. Lucidpipe power system.

These products come in a variety of sizes for different applications: Hydro spin can be installed in pipes as little as $80 \mathrm{~mm}$ in diameter, whereas Hydro-coil is available in 150 and $300 \mathrm{~mm}$ size and Lucidpipe covers the range from 600 to $1500 \mathrm{~mm}$, being most suitable for large scale applications such as urban aqueducts and sewage systems or agricultural districts. Fuji Electric Systems' Micro Tubular Water Turbine shrinks the traditional bulb generator design down to 290,500 and $760 \mathrm{~mm}$ diameter, for a power output from 3 to $250 \mathrm{~kW}$ and the possibility to control flow rate with movable runner vanes. Linepower, developed by Kubota Corporation, also employs a tubular design, fitting the generator right inside the bulb, making the turbine assembly little larger than the $250 \mathrm{~mm}$ conduit and achieving a power output in the 3-90 kW range.

\subsection{External systems}

External systems (Fig. 5) do not depend so strictly on pipe size since the runner is enclosed in a dedicated conduit, and allow for even greater flexibility. Their main drawback is the need for larger vaults to accommodate the turbine and generator assembly, making them less ideal for retrofit intervention on existing water infrastructures.

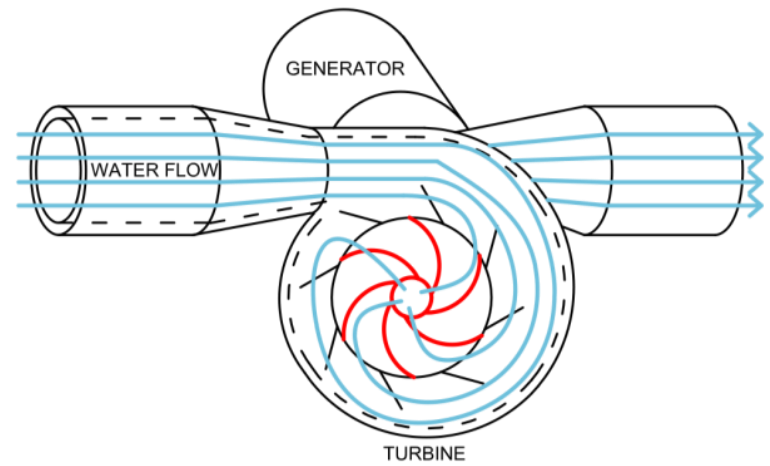

Fig. 5. External systems.

Most products available on the market, such as Rentricity Flow to Wire (Fig. 6) or Sustainable Energy and Monitoring Systems (SEMS), Leviathan Benkatina (Fig. 7) or Hitachi Energy Recovery System, employ Francis design turbines with a rated power that goes from 3-10 kW (Benkatina OG2, Hitachi ERS) to 5-30 kW (Rentricity SEMS) for smaller applications, whereas large scale applications (30-350 kW) are covered by Rentricity Flow to Wire Systems. These systems are usually customized to meet the existing pipe size, whereas the turbine and generator are chosen based on available water flow and head. 


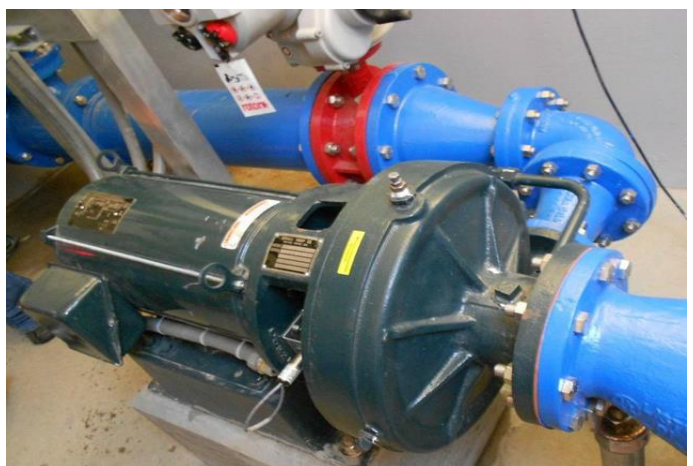

Fig. 6. Rentricity flow-to-wire system.

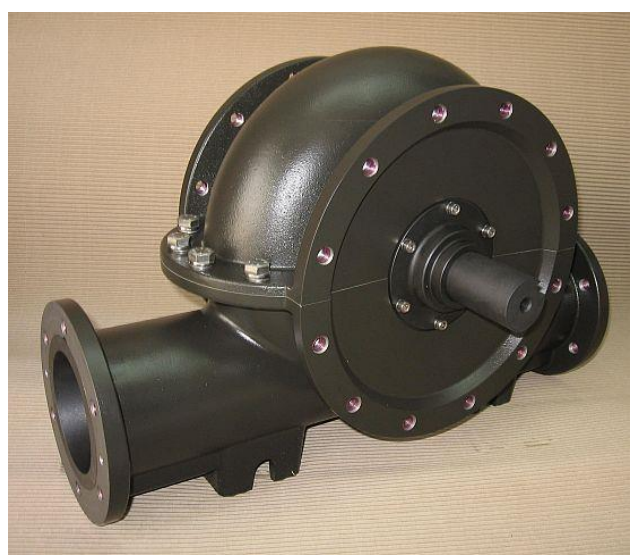

Fig. 7. Leviathan benkatina OG2.

\section{Main Applications of in Pipe Hydro Power Systems}

All cities are served by pressured piping grids systems to supply water where it is needed for drinking, domestic o industrial use, while drain and sewage systems are usually gravity fed. Both hold untapped energy deriving from abundant pressure, and drinking water processors and industrial manufacturers typically install pressure reduction valves ("PRVs") - hydraulic devices that maintain pre-set pressure ranges - to relieve the excess pressure and release it as waste heat. Theoretically, all systems that employ pressure reducing devices could replace them with in pipe generators, maintaining the same control on water flow and pressure whilst producing usable electricity.

\subsection{Urban applications}

On a large, urban grid scale these systems can find several applications.

Small turbines can be used to power water metering and control stations that are isolated from the electrical grid. These generators cause a negligible loss of water head and supply power continuously, constituting a viable alternative to wind turbines and photovoltaics, which suffer from inconsistent operation and need back up batteries, and gasoline power units that need constant refueling and maintenance and are of course very polluting. The possibility to install several self powered control units in different places of the water grid allows for the best control and awareness of its condition and operativeness to reduce water lost due to spilling and leaks, in particular in countries where the water resource is scarce and the infrastructure aging. In the US alone leaking pipes account for an estimated 7 billion gallons of water each day, according to the American Society of Civil Engineers [8]. In Israel, the company Hydro Spin is deploying several micro turbines to power pressure regulators, flow and water quality measurers that supply control centers with $24 / 7$ data and allow for quick responses in case of 
leakage or pressure loss.

Of course the harvested energy can be returned to the electric grid and used alongside other renewable and traditional energy sources, as demonstrated by several ongoing and completed projects all around the world.

In particular, in 2015 the city of Portland made the news by installing a Lucidpipe Power System in one of its main water lines: the four 42" vertical axis turbines total $200 \mathrm{~kW}$ power and are expected to generate an average of $1100 \mathrm{MWh}$ each year serving approximately 150 homes. A three turbine $60 \mathrm{~kW}$ Lucidpipe system has also been installed in San Antonio, Texas, while the pilot installation in Riverside, California (Fig. 8) has been active since January 2012.

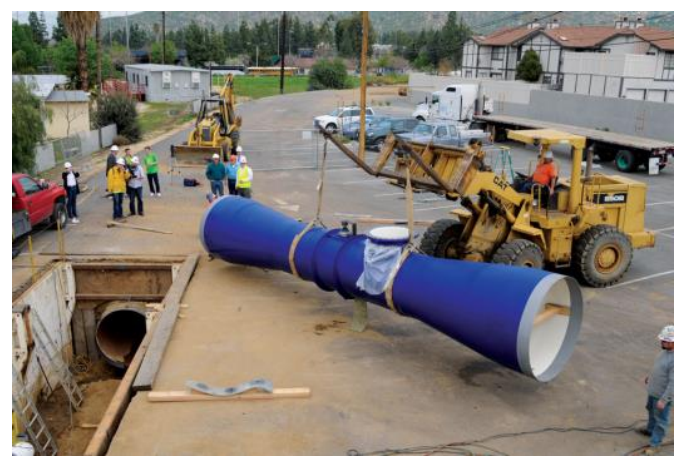

Fig. 8. Lucidpipe installation in Riverside, California.

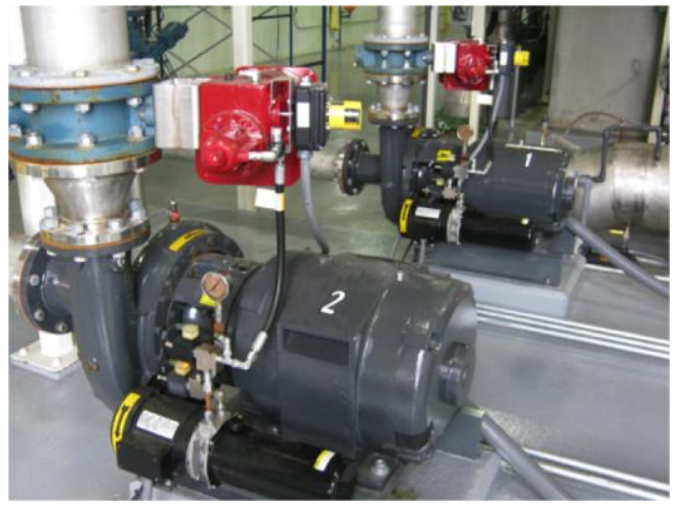

Fig. 9. Rentricity flow-to-wire installation, Keene, NH.

Rentricity has also been very active in North America, with installations in the cities of Halifax, Barre, Oneida Valley and in the Westmoreland County, spanning a 10-50 $\mathrm{kW}$ power range. In particular, the water treatment facility of the city of Keene, New Hampshire (Fig. 9), has been equipped with two turbine generators with different capacities running in parallel, to maximize power yield at all operating conditions: Turbine Generator no. 1 at 720 GPM, generating 17 to $18 \mathrm{~kW}$ power, Turbine Generator no. 2 at 1440-1470 GPM, generating 36 to $38 \mathrm{~kW}$ power, Turbine Generators 1 and 2 operating in parallel at 2070-2170 GPM, generating 50 to $55 \mathrm{~kW}$ power.

The city of Los Angeles is also in talks to install a $225 \mathrm{~kW}$ Flow to Wire system in a transfer station between two municipal reservoirs.

Another interesting application is planned in Hong Kong: the Municipal Water Supplies Department partnered with the Department of Building Services Engineering of Hong Kong Polytechnic University to turn some of its $7800 \mathrm{~km}$ of water mains into a source of power. Researchers developed a 8 blades spherical turbine able to output 80 Volts and tested it in several locations across the city. The plan is to install an array of microturbines to generate $700 \mathrm{kWh}$ per year, reducing carbon dioxide emissions by 560 $\mathrm{kg} / \mathrm{yr}$. 


\subsection{Building applications}

Another large potential energy source lies in the piping systems of single buildings, both for tap water supply, drainage and cooling and heating circuits, with particular regard to large building such as commercial and residential high-rises or shopping malls. In particular, skyscrapers require large amounts of pressure to supply water to the higher floors, and the excess pressure in the lower section is usually wasted via PRVs and could be harvested for powering buildings appliances.

Hong Kong real estate developer Sino Group is collaborating with Arup and Hong Kong Polytechnic University to install their $100 \mathrm{~W}$ vertical axis turbine in building pipelines. A first prototype was installed in the Olympian City 2 shopping mall with the aim of powering an elevator lighting systems. The company is also installing turbines in an apartment development to power lighting systems in stairwells, elevators and lobby.

Another building application employs flow and pressure of hot and cold return water piping of large air conditioning systems (Fig. 10): Hitachi Energy Recovery System uses a vertical axis Francis turbine with integrated electric generator to provide a compact assembly in $3 \mathrm{~kW}$ and $9 \mathrm{~kW}$ size, already tested in the Iwatsuki office of Fuji Xerox (2 units outputting $2.4 \mathrm{~kW}$ each with $25 \mathrm{~m}$ water head) and in Koyo Paper (9.6 kW with $40 \mathrm{~m}$ head) and NGK Spark Plug (6.0 kW with $25 \mathrm{~m}$ head) factories.

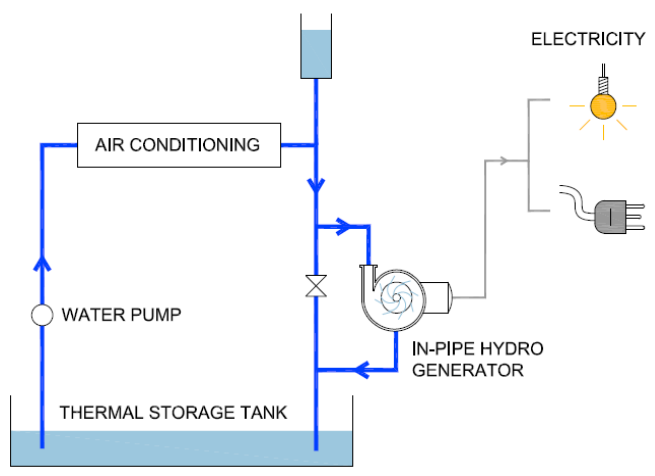

Fig. 10. Integration of in-pipe hydro in air conditioning systems .

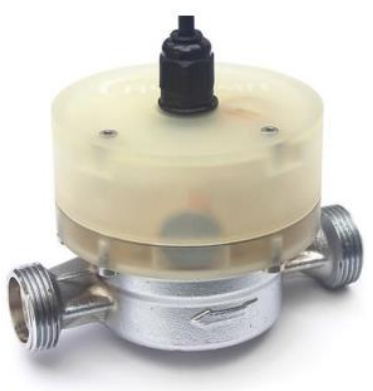

Fig. 11. Radial-flux energy harvester.

For single habitation units applications, reduced space and water head requirements become paramount for any integration of energy harvesting devices in existing piping systems without impeding water flow.

These machines usually have little energy output - less than $1 \mathrm{~W}$ - and are best suitable for powering metering and control devices or small lighting systems.

Scientists from HSG-IMIT and IMTEK developed an automatic remote water meter powered by an energy harvester able to generate up to $720 \mathrm{~mW}$ when using a flow rate of $20 \mathrm{l} / \mathrm{min}$, corresponding to a fully opened water tab [9]. This way it is possible to add metering devices anywhere in existing piping systems without the need for electric and data connections since the devices is self-powered and transmits 
data via $\mathrm{Wi}-\mathrm{Fi}$, and to integrate water monitoring to any building automation system or to other internet of things devices with positive effect on water consumption and energy reduction. The energy harvester itself is based on an impeller wheel directly coupled with an electromagnetic energy transducer, constituted by a two pole ring magnet and three induction coils along with a battery (Fig. 11)

\section{Considerations on the Productivity of in Pipe Hydro Power Systems}

As widely stated, in-pipe hydro technology is now mature enough to allow larger scale use both in urban centers and on buildings in particular.

These systems from the one hand could expand the renewable energy sources at urban scale in the aim of a distributed energy model, from the other hand could work in synergy with the other renewable systems with discontinuous productivity and provide large amounts of electric renewable power otherwise not reachable at building scale. In addition to this, the electric production of in-pipe hydro systems, largely unaffected by climatic conditions, could be the same independently from location and latitude, provided water pipes have enough pressure.

Therefore, it's important to show the potential of these systems compared to photovoltaic and wind building installations to underline the convenience to install these systems when technically feasible.

With this aim, in relation to the various possible conditions of available pressure and water head in existing pipes along with wind speed and solar radiation, the performances of a Lucidpipe turbine, a vertical axis Gorlov design wind turbine and a monocrystalline silicon photovoltaic module have been compared in terms of power, electric productivity and area required. Data used for the analysis were taken from specifications provided by the manufacturers (see Table 2).

Table 2. Characteristics and performance of compared in-pipe hydro system, wind turbine and photovoltaic module

\begin{tabular}{|c|c|c|c|c|c|c|}
\hline \multicolumn{7}{|c|}{ In-pipe Hydro Power System } \\
\hline Producer & Model & $\begin{array}{c}\text { Rated Power } \\
\text { kW }\end{array}$ & $\begin{array}{c}\text { Productivity } \\
\text { kWh/year } \\
\text { (60\% capacity) }\end{array}$ & $\begin{array}{l}\text { Pipe diameter } \\
\text { mm }\end{array}$ & $\begin{array}{c}\text { Rated Water } \\
\text { Flow } \\
\mathrm{m}^{3} / \mathrm{s}\end{array}$ & $\begin{array}{c}\text { Rated water } \\
\text { head pressure } \\
\mathrm{m}\end{array}$ \\
\hline Lucidenergy & Lucidpipe & 14 & 73584 & 600 & 1.0 & 32 \\
\hline Lucidenergy & Lucidpipe & 50 & 262800 & 1000 & 2.7 & 35 \\
\hline Lucidenergy & Lucidpipe & 100 & 525600 & 1500 & 5.6 & 27 \\
\hline \multicolumn{7}{|c|}{ Gorlov Design Wind Turbine } \\
\hline Producer & Model & $\begin{array}{c}\text { Power } \\
\mathrm{kW}(\mathrm{m} / \mathrm{s})\end{array}$ & $\begin{array}{c}\text { Productivity } \\
\text { kWh/year (m/s) }\end{array}$ & Height $\mathrm{m}$ & Swept area $\mathrm{m}^{2}$ & $\begin{array}{c}\text { Minimum } \\
\text { production } \\
\text { speed } \mathrm{m} / \mathrm{s}\end{array}$ \\
\hline UGE & $4 \mathrm{~K} \mathrm{GT}$ & $4.0(12)$ & $10000(7)$ & 4.6 & 13.8 & 3.5 \\
\hline \multicolumn{7}{|c|}{ Photovoltaic Module } \\
\hline Producer & Model & $\begin{array}{c}\text { Power } \\
\text { Wp }\end{array}$ & $\begin{array}{c}\text { Module } \\
\text { efficiency }\end{array}$ & Cell type & $\begin{array}{c}\text { Solar cells per } \\
\text { module }\end{array}$ & $\begin{array}{l}\text { Module size } \\
\mathrm{mm}\end{array}$ \\
\hline Schott & $\begin{array}{l}\text { Perform Mono } \\
250\end{array}$ & 250 & $14.9 \%$ & $\begin{array}{l}\text { Monocrystalline } \\
\text { Silicon }\end{array}$ & 60 & $993 \times 1685$ \\
\hline
\end{tabular}

Table 3. Comparison between in-pipe hydro system, PV and vertical wind systems at the same power output

\begin{tabular}{lcccc}
\hline System & $\begin{array}{c}\text { Unit } \\
\text { power }\end{array}$ & $\begin{array}{c}\text { Area or area/installed } \\
\text { power ratio }\end{array}$ & $\begin{array}{c}\text { Number of elements to } \\
\text { supply same power } \\
\text { output }\end{array}$ & $\begin{array}{c}\text { Total Area required to } \\
\text { supply same power } \\
\text { output }\end{array}$ \\
\hline Lucidpipe Power systems $(600 \mathrm{~mm})$ & $14 \mathrm{~kW}$ & $10 \mathrm{~m}^{2}$ & 1 turbine & $10 \mathrm{~m}^{2}$ \\
UGE 4k & $4 \mathrm{~kW}$ & $25 \mathrm{~m}^{2} / \mathrm{kW}$ & 4 turbines & $400 \mathrm{~m}^{2}$ \\
Schott Solar Perform Mono 250 & $250 \mathrm{~W}$ & $7 \mathrm{~m}^{2} / \mathrm{kW}$ & 56 panels & $98 \mathrm{~m}^{2}$ \\
\hline
\end{tabular}

Lucidpipe Power systems come in different diameters to adapt to different existing ducts of any material: turbines with $600 \mathrm{~mm}, 1000 \mathrm{~mm}$ and $1500 \mathrm{~mm}$ yield a rated power of $14 \mathrm{~kW}, 50 \mathrm{~kW}$ and 100 $\mathrm{kW}$, output in 240 volt, 3 phase AC, at a water pressure head of $27-32 \mathrm{~m}$ and a water speed of $3 \mathrm{~m} / \mathrm{s}$.

The actual power output for a given pipe diameter is dependent on water flow and thus water speed (Fig. 12). The operating range spans water speed values typical of urban water grids, with cut-in speed of 
$0.9 \mathrm{~m} / \mathrm{s}$ and cut-out speed of $2.7 \mathrm{~m} / \mathrm{s}$ and water head extraction between 1 and $4 \mathrm{~m}$ according to different water speed values. Considering a $1000 \mathrm{~mm} 50 \mathrm{~kW}$ turbine, power to pressure extraction ratio ranges from $3.90 \mathrm{~kW} / \mathrm{m}$ at $0.9 \mathrm{~m} / \mathrm{s}$ (cut -in speed) to a maximum value of $14.25 \mathrm{~kW} / \mathrm{m}$ at $3.57 \mathrm{~m} / \mathrm{s}$, correspondent to the rated flow value of $2.7 \mathrm{~m}^{3} / \mathrm{s}$.

Turbines stop in case of excessive water speed or to preserve water head in the duct, as pressure extraction in the stopped position is up to $0.7 \mathrm{~m}$ allowing a virtually normal system operation.

Lucidpipe system is also modular, as multiple turbines can be installed in the same duct to extract more water pressure and electricity: available pressure for extraction can be obtained by comparing the duct's operating pressure with its minimum required operating pressure for normal operation; the number of deployable turbines is then determined by dividing this gap by a single turbine's extraction (1-4 m). Turbines should be placed 3-4 diameters apart, so a $12 \mathrm{~m}$ section of $600 \mathrm{~mm}$ diameter pipeline could accommodate up to 5 different $14 \mathrm{~kW}$ turbines, outputting $70 \mathrm{~kW}$ of electric power. Finally, the system takes almost no space, requiring just a little vault for allocating the generator.

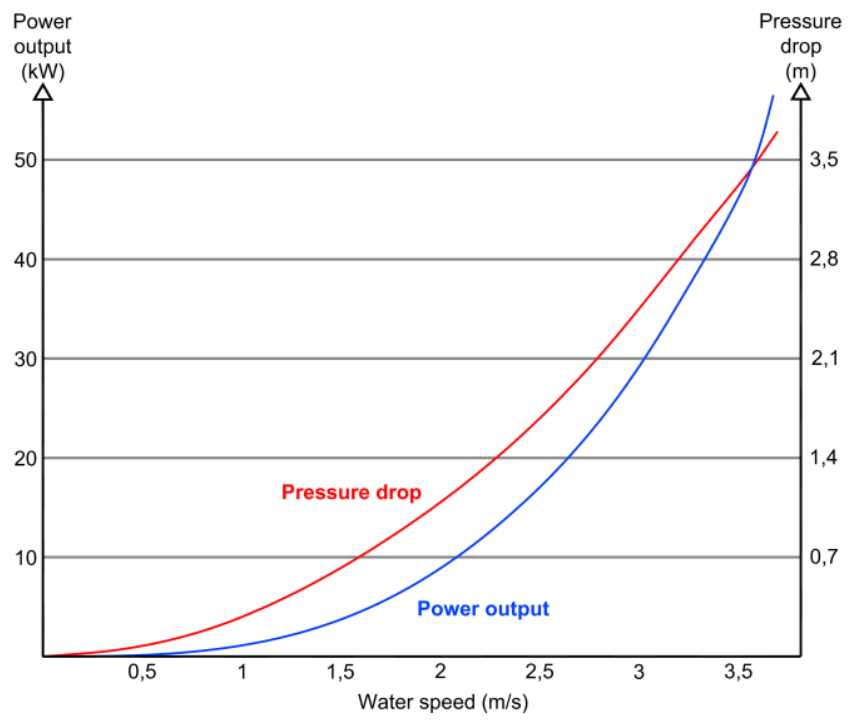

Fig. 12. Power/Pressure drop chart of a lucidpipe $1000 \mathrm{~mm}$ power system.

For comparing wind energy, a UGE 4k turbine was considered for its compact size and high efficiency even at lower wind speeds that make it ideal for building integration. This $4.50 \mathrm{~m}$ high, $3.00 \mathrm{~m}$ wide Gorlov design turbine has a rated power of $4 \mathrm{~kW}$ at a wind speed of $12 \mathrm{~m} / \mathrm{s}$. Wind turbines must be placed at least 4 diameters apart $(12 \mathrm{~m})$ to minimize interference and turbulences that would undermine overall productivity, therefore each turbine needs more than $100 \mathrm{~m}^{2}$ of available space $\left(25 \mathrm{~m}^{2} / \mathrm{kW}\right)$.

Finally, Schott Solar Perform Mono 250 was taken as reference for solar power estimation. Each 1.685 mm x $993 \mathrm{~mm}$ monocrystalline silicon module yields $250 \mathrm{~W}$ power, with a peak efficiency of $14.94 \%$ and a required area of $7 \mathrm{~m}^{2} / \mathrm{kW}$.

From the comparison of the three systems it is apparent at first that the area/installed power ratio of in pipe hydro (assumable in around $10 \mathrm{~m} 2$ independently from installed power) is much lower than photovoltaic $\left(7 \mathrm{~m}^{2} / \mathrm{kW}\right)$ and wind systems $\left(25 \mathrm{~m}^{2} / \mathrm{kW}\right.$ considering each turbine respect area). Therefore, as shown in Table 3, to install $14 \mathrm{kWp}$ of electric power, a single in-pipe turbine $600 \mathrm{~mm}$ diameter is sufficient, whereas other renewable energy sources would require a rather big area, not always available at a single building scale, equal to $98 \mathrm{~m}^{2}$ of monocrystalline PV modules or 4 wind turbines taking up 400 $\mathrm{m}^{2}$.

At the same power output, to compare electric productivity different values for wind speed (1 to 11 $\mathrm{m} / \mathrm{s}$ ) and average annual solar radiation (500 to $3000 \mathrm{kWh} / \mathrm{m}^{2} \mathrm{yr}$ ) were taken in to account (Table 4).

Regarding the in-pipe hydro system, it's productivity can be calculated conservatively assuming that 
the generator would be running full time $(8760 \mathrm{~h} / \mathrm{yr})$ at rated peak conditions of water flow and head pressure for $60 \%$ of the time, values compatible with the average urban water main duct. In these conditions the productivity can be estimated equal to $5256 \mathrm{kWh} / \mathrm{kWyr}$.

Concerning photovoltaic productivity, this it was estimated for different average annual solar radiation values assuming installations with optimal Azimuth and tilt according to different latitudes and a $\eta_{\text {BOS }}$ value equal to $85 \%$. The analysis shows values comprised between 446 and $2678 \mathrm{kWh} / \mathrm{kW}_{\mathrm{p}} \mathrm{yr}$.

Finally wind power productivity was devised from the manufacturer's power output chart at the different average wind speed values. The analysis shows values comprised between 250 and 4000 $\mathrm{kWh} / \mathrm{kWyr}$.

Table 4. Comparison between wind turbine and PV systems productivity

\begin{tabular}{|c|c|c|c|c|c|c|c|c|}
\hline \multicolumn{5}{|c|}{ UGE 4K GT Wind Turbine4 kW } & \multicolumn{4}{|c|}{ Schott Perform MONO 250W PV Panel } \\
\hline $\begin{array}{l}\text { Average } \\
\text { Annual } \\
\text { Wind } \\
\text { Speed } \\
\mathrm{m} / \mathrm{s}\end{array}$ & $\begin{array}{l}\text { Productivity } \\
\mathrm{kWh}_{\mathrm{e}} / \mathrm{kW}\end{array}$ & $\begin{array}{l}\text { Produced } \\
\text { Energy } \\
\mathrm{kWh}_{\mathrm{e}} / \mathrm{yr}\end{array}$ & $\begin{array}{l}\text { Productivity } \\
\mathrm{kWh}_{\mathrm{e}} / \mathrm{m}^{2}\end{array}$ & $\begin{array}{l}\text { Required } \\
\text { area } \\
\mathrm{m}^{2} / \mathrm{MWh}_{\mathrm{e}}\end{array}$ & $\begin{array}{l}\text { Annual } \\
\text { Solar } \\
\text { Irradiance } \\
\mathrm{kWh} / \mathrm{m}^{2}\end{array}$ & $\begin{array}{l}\text { Productivity } \\
\mathrm{kWh}_{\mathrm{e}} / \mathrm{kWp}\end{array}$ & $\begin{array}{l}\text { Productivity } \\
\mathrm{kWh}_{\mathrm{e}} / \mathrm{mq}\end{array}$ & $\begin{array}{l}\text { Required } \\
\text { area } \\
\mathrm{m}^{2} / \mathrm{MWh}_{\mathrm{e}}\end{array}$ \\
\hline 1 & 0 & 0 & - & - & 500 & 446 & 63.71 & 15.70 \\
\hline 2 & 250 & 1000 & 8.84 & 113.12 & 750 & 669 & 95.57 & 10.46 \\
\hline 3 & 500 & 2000 & 17.6 & 56.56 & 1000 & 893 & 127.57 & 7.84 \\
\hline 4 & 750 & 3000 & 26.52 & 37.70 & 1250 & 1116 & 159.43 & 6.27 \\
\hline 5 & 1250 & 5000 & 44.20 & 22.62 & 1500 & 1339 & 191.29 & 5.23 \\
\hline 6 & 1875 & 7500 & 66.30 & 15.08 & 1750 & 1562 & 223.14 & 4.48 \\
\hline 7 & 2500 & 10000 & 88.40 & 11.31 & 2000 & 1785 & 255.00 & 3.92 \\
\hline 8 & 3250 & 13000 & 114.92 & 8.13 & 2250 & 2008 & 286.86 & 3.49 \\
\hline 9 & 4000 & 16000 & 141.44 & 7.07 & 2500 & 2231 & 318.71 & 3.14 \\
\hline 10 & 4000 & 16000 & 141.44 & 7.07 & 2750 & 2454 & 350.57 & 2.85 \\
\hline$\geq 11$ & 4000 & 16000 & 141.44 & 7.07 & 3000 & 2678 & 382.57 & 2.61 \\
\hline
\end{tabular}

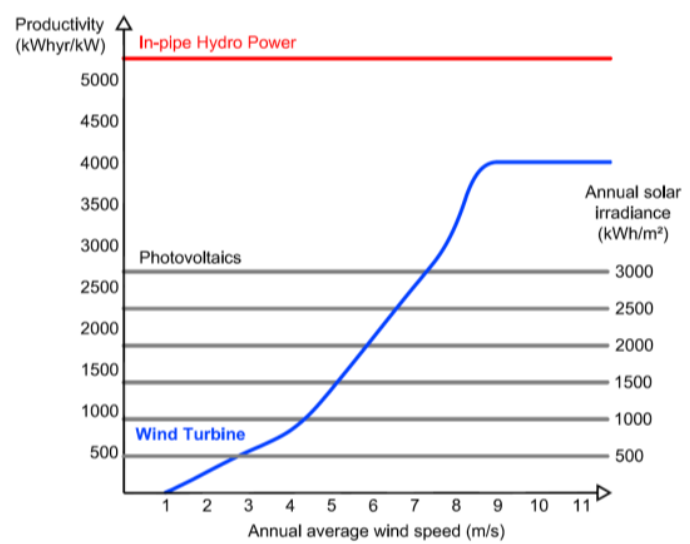

Fig. 13. Productivity comparison between renewable energy systems.

As shown in Fig. 13, from the comparison between the three systems emerges that productivity of inpipe hydro is higher than both PV and wind systems at any climatic condition. In particular in-pipe hydro productivity is:

- From 2 to 11 times higher than PV with an average ratio of 3-5 at latitudes between 38 and $55 \mathrm{~N}$;

- From 1 to 21 times higher than wind with an average ratio of 1.5-7 at a average annual wind speed between $8.5 \mathrm{~m} / \mathrm{s}$ and $4 \mathrm{~m} / \mathrm{s}$.

The difference between the three systems is even more evident considering the area required to produce the same amount of energy per year. This is because the productivity gap shown above adds up to the already better power/area ratio of in-pipe hydro systems

It is apparent how the balance between different renewable energy sources varies greatly according to 
different locations and therefore climatic conditions. Any real world application should thus identify the most viable and productive energy mix considering pipes flow and pressure, solar radiation and wind speed together. As real world example three different locations were considered for both wind and solar installations to compare to in-pipe hydro power systems: Copenhagen (Denmark), representative of northern European locations (lat. 55 41' 0 ' $\mathrm{N}$ ) with excellent average yearly wind speed $(8.5 \mathrm{~m} / \mathrm{s}$ ) but low solar radiation $\left(1025 \mathrm{kWh} / \mathrm{m}^{2} \mathrm{yr}\right.$ ), Rome (Italy), a large Southern Europe city (lat. 41 53'35' N) with good solar radiation $\left(1737 \mathrm{kWh} / \mathrm{m}^{2} \mathrm{yr}\right)$ but low average wind speed $(4 \mathrm{~m} / \mathrm{s})$, and Trapani (Italy), a Mediterranean coastal town (lat. 381 ' 0 ' $N$ ) with excellent solar radiation $\left(1963 \mathrm{kWh} / \mathrm{m}^{2} \mathrm{yr}\right.$ ) and good average wind speed $(6 \mathrm{~m} / \mathrm{s})$.

Fig. 14 shows clearly how location influences the performance, with particular regard to wind energy where little speed variations can greatly alter productivity. In the case of Rome, wind energy underperforms $\left(750 \mathrm{kWh} / \mathrm{kW}\right.$ yr) while solar energy shows good values $\left(1477 \mathrm{kWh}_{\mathrm{e}} / \mathrm{kW}\right.$ yr) making it preferable.

On the other hand, a city like Copenhagen has outstanding wind performance $\left(3750 \mathrm{kWh}_{\mathrm{e}} / \mathrm{kW} \mathrm{yr}\right.$ ), not far from in-pipe hydro power values, but only $928 \mathrm{kWh}_{\mathrm{e}} / \mathrm{kW}$ yr from solar energy, hindered by its high latitude and low solar irradiance. Mediterranean coastal sites such as Trapani get the best of both worlds with good results in both solar energy $\left(1669 \mathrm{kWh}_{\mathrm{e}} / \mathrm{kW} \mathrm{yr}\right)$ and wind productivity $(1875 \mathrm{kWh} / \mathrm{kW} \mathrm{yr})$ making it most suitable for a balanced mix of renewable energy sources.

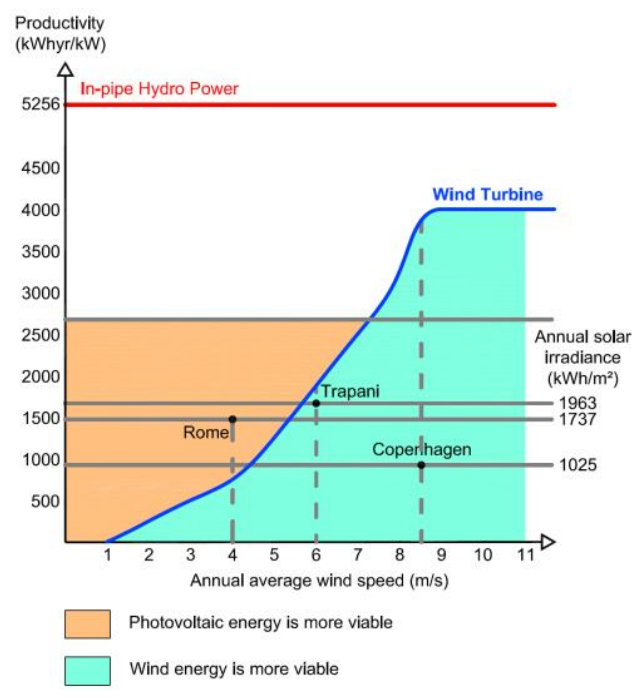

Fig. 14. Productivity comparison in real world applications.

In any case in-pipe hydro power values are unreachable by other renewable energy sources, allowing to exploit effectively overpressures normally present in all urban water piping grids.

Hydropower convenience is even more evident if the area required to supply a given amount of electric power per year is considered: regardless of location, a single $14 \mathrm{~kW}$ in-pipe hydro power installation (600 mm diameter) produces $73584 \mathrm{kWh}$ yr taking up as little as a $10 \mathrm{~m}^{2}$ vault, whereas the same amount of power would require from 650 to over $3000 \mathrm{~m}^{2}$ for wind and from around 300 up to $600 \mathrm{~m}^{2}$ for PV solar in the considered cities.

\section{Conclusions}

The integrated and intelligent electricity system of future smart cities goes through a model of distributed energy generation which provides maximum integration of renewable energy sources in urban centers [10]. 
Among the different renewable energy sources that are nowadays suitable for integration in urban areas, in addition to photovoltaic and vertical axis wind systems, particularly interesting are small scale hydro systems, with power output from 5 to $100 \mathrm{~kW}$ (micro Hydro), installed in urban or industrial water supply grids and waste drainage networks.

Analysis performed shows in fact that in-pipe systems can offer many advantages both in terms of quantity of energy produced and supply continuity without the problems of architectural integration and dependence on weather conditions typical of photovoltaic and wind systems, making it strongly recommended whenever water grid conditions allow its installation.

In addition to providing clean energy, the application of these systems can help improving the management of water networks, allowing to monitor and adjust the water flows and to optimize overpressure, thus lengthening service life of all equipment.

These systems can be installed anywhere upstream of a pressure-transient zone in a gravity-fed pipeline, wherever power is desired, and operate across a wide range of flow conditions without the need for pumps to create back-pressure and velocity adjustments.

Several cities such as Portland, Los Angeles and Hong Kong have started testing those systems at urban scale producing electricity for thousands of homes by exploiting the excess pressure of water supply, otherwise wasted through traditional pressure reduction devices.

Energy is often the single largest expense for many water utilities, representing $40 \%-50 \%$ of a water agency's annual operating budget [11]. In-pipe power systems can provide municipalities with an opportunity to reduce costs and reliance on grid-based power by using their existing water infrastructure to generate cost-effective renewable energy.

Furthermore, systems below $5 \mathrm{~kW}$ (pico hydro) can find interesting applications in buildings and highrises in particular, by exploiting the overpressure normally available on the lower floors or integrated in the pipes of single habitation units along with measuring sensors, constituting self powered water monitoring tools able to transmit via Wi-Fi information such as water consumption, operating temperature and water quality and contributing to the intelligent management of all energy services of the building (Internet of things).

Therefore, in order to promote these promising renewable energy systems, it's advisable to expand, coordinate and disseminate results of in-pipe micro and pico hydro technology development to improve operational performance, reduce costs and foster technologies to better support the grid integration of large amounts of variable renewable energy, in order to achieve a clean and resilient electricity system that supports efficient, flexible, reliable and affordable operation.

\section{References}

[1] OECD/IEA. Key World Energy Statistics. Paris: IEA Publications; 2014:1-80.

[2] OECD/IEA. World Energy Outlook. Paris: IEA Publications; 2014:1-748

[3] World Energy Council. World Energy Resources, 2013 Survey. 2013:1-468.

[4] Global Wind Energy Council. Global Wind Statistics. 2014. 2015:1-5.

[5] IEA PVPS. Snapshot of Global PV Markets 2014, 2015:1-16.

[6] IEA. Technology Roadmap, Hydropower. 2012:1-61.

[7] Pichs-Madruga R, Sokona Y, Seyboth K, Matschoss P, Kadner S, Zwickel T, et al. Intergovernmental panel on climate change working group III Edenhofer O. IPCC Special Report on Renewable Energy Sources and Climate Change Mitigation. Cambridge: Cambridge University Press; 2012:1-1075.

[8] American society of civil engineers. Report Card for America's Infrastructure Executive Summary. 2009:1.

[9] Hoffmann D, Willmann A, Göpfert R, Becker P, Folkmer B, Manoli Y. Energy harvesting from fluid flow in water pipelines for smart metering applications. Journal of Physics: Conference Series, 2013; 476:1-5.

[10] IEA. Energy Technology Perspectives, Harnessing Electricity's Potential. Paris: IEA Publications; 2014:1-382.

[11] Copeland C. Energy-water nexus: the water sector's energy use. CRS Report R43200, Washington DC: Congressional Research Service; 2014:1-10. 